\title{
TO THE ISSUE OF MODERNIZATION OF PROFESSIONAL LINGUIDACTIC TRAINING OF FUTURE TEACHERS OF ELEMENTARY CLASSES OF A NEW UKRAINIAN SCHOOL
}

УДК 378.147:371.1:8

DOI https://doi.org/10.32843/2663$6085 / 2021 / 31-2.41$

Пріма д.А.,

докт. пед. наук,

доцент кафедри теорії і методики початкової освіти

Волинського національного

університету імені Лесі Українки

\section{Вітюк В.В.,}

канд. пед. наук,

доцент кафедри теорії і методики

початкової освіти

Волинського національного

університету імені Лесі Українки
Актуалізовано необхідність модернізації початкової освіти задля забезпечення вимог Нової української школи та інтеграції національної освіти в європейський і світовий освітній простір, професійної підготовки конкурентоспроможних компетентних фрахівців. Проаналізовано деякі аспекти професійної лінгводидактичної підготовки в контексті модернізації системи педагогічної освіти. Узагальнено, що в педагогічній науці існує тенденція до перманентного пошуку шляхів удосконалення системи, форм і методів підготовки майбутніх учителів початкової школи, яка ґрунтується на загальних принципах побудови навчальновиховного процесу в закладах вищої освіти для формування у здобувачів освіти першого рівня повної загальної середньої освіти предметних компетентностей. Акцентовано на необхідності оволодіння майбутнім учителем Нової української школи інноваційними технологіями, науково-практичними надбаннями вітчизняної й зарубіжної лінгводидактики, зокрема у площині формування ї орфоограсрічної та пунктуаційної грамотності і правописної компетентності в цілому.

Ключові слова: майбутній учитель початкових класів, модернізація, нова українська школа, педагогічна освіта, правописна компетентність, профресійна лінгводидактична підготовка.

The necessity of modernization of primary education in order to ensure the requirements of the new Ukrainian school and the integration of national education into the European and world educational space, professional training of competitive competent specialists is updated. Some aspects of professional linguidactic training in the context of modernization of the system of pedagogical education are analyzed. Generalized that in pedagogical science, there is a tendency for the permanent search of ways to improve the system, forms and methods for preparing future elementary school teachers, which is based on the general principles of building a educational process in higher education institutions for the formation of the first level of full general secondary education of the substantive competence. The emphasis on the future teacher of the new Ukrainian school with innovative technologies, scientific and practical achievements of domestic and foreign linguidactics, in particular in the plane of forming their spelling and punctual literacy and spelling competence as a whole.

Key words: upcoming elementary class teacher, modernization, new Ukrainian school, pedagogical education, spelling competence, professional linguistic tactical training.
Постановка проблеми у загальному вигляді та зв'язок із важливими науковими чи практичними завданнями. Нині в умовах модернізації початкової освіти постає необхідність переосмислити нагромаджену практику профресійної підготовки педагогів для забезпечення вимог Нової української школи та інтеграції національної освіти в європейський і світовий освітній простір. Загальновідомо, що провідна роль у фрормуванні здобувачів початкової освіти належить учителю початкової школи, адже саме він закладає фрундаментальні основи інтелектуального, духовного, творчого, культурного потенціалу майбутньої української нації.

У нашому розумінні модернізація - це зміни відповідно до потреб та вимог сучасності. У Великому тлумачному словнику сучасної української мови «модернізація означає змінювати, вдосконалювати відповідно до сучасних вимог» [1, с. 242]. В українській енциклопедії модернізація тлумачиться як «зміна, удосконалення, яке відповідає сучасним вимогам» [2, с. 132].

3 огляду на це можна стверджувати, що модернізація змісту початкової освіти передбачає оновлення освітніх систем, зокрема створення нових освітніх стандартів, типових освітніх і модульних програм, підручників, фрорм і методів навчання.

Модернізація системи вищої педагогічної освіти України вимагає оновлення діяльності закладів вищої освіти 3 урахуванням національних надбань світового значення та кращого європейського досвіду, забезпечення професійної підготовки конкурентоспроможних компетентних фрахівців, які зможуть повноцінно виконувати багатофрункційну педагогічну діяльність [3, с. 22].

Актуальність проблеми професійної підготовки вчителів відображено в Законах України «Про освіту», «Про вищу освіту», Національній доктрині розвитку освіти України у XXI ст. , Національній стратегії розвитку освіти в Україні на період до 2021 року, Концепції реалізації державної політики у сфері реформування загальної середньої освіти «Нова українська школа» на період до 2029 року, Державному стандарті початкової загальної освіти Професійному стандарті «Вчитель початкової школи», Національній рамці кваліфікацій, Галузевій концепції розвиту неперервної педагогічної освіти , Концепції Нової української школи, Концепції розвитку педагогічної освіти та ін. 
Зауважимо, лінгводидактична підготовка у площині зазначених нормативно-правових документів набуває пріоритетного значення, позаяк

виховувати, розвивати, соормувати школяра як людину, індивідуальність, особистість, навчити його продуктивно мислити не можна без оволодіння рідною мовою як засобом спілкування [4]. Відтак, мовна освіта в загальноосвітній і вищій школах орієнтується на фрормування національно-мовної особистості - людини, здатної вільно й комунікативно доцільно спілкуватися літературною мовою в різних сорерах суспільного життя, мати високий рівень національної свідомості, бути патріотом рідної мови.

Аналіз досліджень і публікацій з проблеми підготовки майбутніх учителів початкових класів засвідчує науковий інтерес до проблеми модернізації змісту освіти на основі фрормування ключових компетентностей молоді, що студіюються у працях сучасних учених Н. Козакова, С.Литвиненко, О. Овчарук, О. Савченко, Г. Черненко та інших. Нині помітно активізувалася зацікавленість науковців багатоаспектною проблемою фрормування правописної компетентності майбутніх учителів початкової школи (В. Бадер, Н. Бібік, Н. Богданець-Білоскаленко, А. Богуш, М. Вашуленко, С. Дубовик, К. Климова, М. Оліяр, Н. Ростикус, Н. Сіранчук, О. Чупріна та ін.). Теоретичний та практичний аспекти навчання правопису в учнів закладів загальної середньої освіти висвітлено в публікаціях О. Біляєва, Н. Бондаренко, М. Вашуленка, Н. Голуб, О. Гончарук, О. Горошкіної, Н. Грони, Н. Іваницької, О. Караман, Н. Ковальчук, С. Омельчука, Е. Палихати, Л. Попової, І. Хом'яка, Н. Шульжук, І. Ющука та ін. Лінгводидактичні засади фрормування правописної компетентності як важливого складника комунікативної вправності майбутнього вчителя розроблено в наукових студіях О. Антончука, А. Богуш, Н. Голуб, О. Горошкіної, М. Вашуленка, Х.Карповець, Н. Ковальчук, В. Мельничайка, М. Пентилюк, І. Хом'яка, О. Хорошковської, Г. Шелехової та ін.

Мета статті: проаналізувати деякі аспекти професійної лінгводидактичної підготовки в контексті модернізації системи педагогічної освіти.

Виклад основного матеріалу й обгрунтування отриманих результатів дослідження. Передусім відзначимо, що у Національній доктрині розвитку освіти наголошено, що «мета державної політики щодо розвитку освіти полягає у створенні умов для розвитку особистості і творчої самореалізації кожного громадянина України, вихованні покоління людей, здатних ефективно працювати і навчатися протягом життя, оберігати й примножувати цінності національної культури та громадянського суспільства, розвивати і зміцнювати суверенну, незалежну, демократичну, соціальну та правову державу як невід'ємну складову європейської та світової спільноти» [5].
Національною стратегією розвитку освіти в Україні на період до 2021 року декларується, що «сучасний розвиток суспільства вимагає вдосконалення системи педагогічної освіти педагогічних працівників відповідно до умов соціально орієнтованої економіки та інтеграції України в європейське і світове освітнє співтовариство» [6]. Концептуальними засадами розвитку вищої педагогічної освіти України та її інтеграцією в Європейський простір вищої освіти [7, с. 7-10] передбачено підготовку нової генерації педагогічних працівників, підвищення їх професіоналізму, національної самосвідомості, готовності до творчої діяльності.

У Концепції Нової української школи зазначено, що українська школа буде успішна, якщо до неї прийде успішний, умотивований, творчий, відповідальний учитель, який постійно працює над собою, який зможе готувати власні авторські навчальні програми, самостійно обирати підручники, методи, стратегії, способи й засоби навчання $[8$, c. 16]. Сучасна роль учителя початкової школи не надавати здобувачам освіти готові знання, а навчити їх здобувати, фрормуючи в собі наполегливість, цілеспрямованість, бажання і здатність учитися самостійно, з інтересом і задоволенням. Спільна робота вчителя та учнів початкової школи сьогодні - це не пояснення та запам'ятовування, а пошук істини, життєвих цінностей і смислів в умовах навчального діалогу, співробітництва та взаєморозуміння.

Аналіз вітчизняних і зарубіжних наукових праць у галузі педагогічної науки дає підстави стверджувати, що проблема профресійної підготовки вчителя знаходиться в центрі уваги багатьох науковців. Так, В. Андрущенко наголошує на необхідності формування «нового вчителя», спроможного засобами освіти готувати людину до життя. За переконаннями вченого, це «є стратегічними завданнями модернізації нашого суспільства загалом» [9, с. 7].

Досліджуючи динаміку розвитку освіти, І. Шапошнікова констатує, що «тенденції зміни парадигми освітніх систем знаходяться у площині пошуку таких варіантів, де б кожна особистість не лише готувалася до соціальної адаптації у швидкоплинному середовищі та пристосовувалася до потреб часу, а й випереджала своїм духовним розвитком застарілі зразки світобачення старших поколінь» [10, с. 78].

На думку В. Кременя, час вимагає фрормування особистості вчителя не лише як носія знань, а й спроможного бути «людиною, яка супроводжує процес самопізнання і саморозвитку дитини, скеровує і динамізує його відповідно до конкретних сутнісних задатків кожної людини. Формувати готовність учителя до цілісного вивчення дитини і готовність, викладаючи конкретний предмет, забезпечувати системний розвиток дитини, системне бачення нею світу, 
готовність органічно поєднувати навчальний виховний процес» [11, с. 4].

Модернізація змісту освіти ставить нові завдання і вимоги до підготовки вчителів початкової школи. Відхід від стереотипізації, перехід до особистісного спрямування освітнього процесу, індивідуалізації навчання, виховання самостійності, творчості, активності життєвої позиції учнів вимагають від учителів широкої обізнаності в галузі своєї професійної діяльності, знань із багатьох сорер, сорормованості умінь органічно поєднувати та застосовувати їх у майбутній діяльності.

3 метою удосконалення системи підготовки майбутніх учителів початкової школи необхідно, на наш погляд, вдаватися до впровадження інноваційних технологій навчання. До проблеми запровадження інноваційних педагогічних технологій звертався і свого часу С. Гончаренко. Учений зазначав, що «розвиток методичної науки в умовах розбудови національної системи освіти набуває особливо важливого значення. Вона має обґрунтувати й будувати педагогічні процеси, виробляти нові педагогічні технології навчання, у яких реалізувалися б мета й принципи нашої освітньої системи, спрямувати вчителя в його повсякденній творчій діяльності, допомогти студентові (майбутньому вчителеві) оволодіти профресією» [12, с. 3]. І. Бех наголошує, що «вчитель у контексті особистісно орієнтованого підходу $€$ не пасивним виконавцем чужих педагогічних чи методичних рецептів, а яскравою творчою індивідуальністю. Умовами формування в педагогів мотивації до інноваційних педагогічних цінностей $є$ опора на досвід, що позитивно переживається» [13, с. 27-28].

Проведений аналіз нормативних документів, наукових досліджень дозволяє дійти висновку, що в педагогічній науці існує тенденція до перманентного пошуку шляхів удосконалення системи, фрорм і методів підготовки майбутніх учителів початкової школи, яка ґрунтується на загальних принципах побудови навчально-виховного процесу в закладах вищої освіти.

3 огляду на це, постає нагальна потреба в розробленні раціональних технологій навчання, які б давали можливість використовувати сучасні педагогічні технології на заняттях 3 курсу «Сучасна українська мови 3 практикумом», «Методика навчання мовно-літературної освітньої галузі» 3 тим, щоб майбутні студенти, які навчаються у закладах вищої освіти, змогли всебічно використовувати фундаментальні знання й творчо застосовувати набуті фрахові вміння для фрормування у здобувачів освіти першого рівня повної загальної середньої освіти предметних компетентностей.

Проведений аналіз наукової літератури та основних тенденцій розвитку освіти XXI століття, державних нормативних документів дають підстави стверджувати, що лінгводидактика вищої школи потребує оновлення свого змісту та запровадження сучасних підходів, технологій, фрорм і методів роботи, які б давали можливість максимально враховувати вимоги й запити суспільства, світової спільноти щодо підготовки майбутніх фрахівців. Досягнення цієї мети потребує істотного посилення самостійної, продуктивної навчальної та науково-дослідницької діяльності студентів, розвитку їхніх особистісних якостей і творчих здібностей, умінь самостійно здобувати нові знання та успішно розв'язувати складні фрахові проблеми.

Якщо професійно-методична підготовка вчителів початкової школи раніше складалася із засвоєння ним традиційної методики навчання української мови, її теоретичних положень і практичних рекомендацій, то нині майбутній учитель Нової української школи потребує оволодіння інноваційними технологіями, науково-практичними надбаннями вітчизняної й зарубіжної лінгводидактики.

Донедавна у практиці окремих закладів вищої освіти задля підвищення рівня мовної підготовки студентів перед кожною іспитовою сесією, а також перед державною атестацією однією з форм перевірки стану правописної грамотності майбутніх учителів початкової школи був диктант як допуск до відповідного виду атестації. 3 часом цей вид діагностики було замінено сучасними інорормаційно-комунікативними технологіями, інноваційними фрормами перевірки мовної компетентності студентів.

Крім того, у Державному стандарті базової i повної загальної освіти 3-поміж інших предметних компетенцій (фонетичної, орфрографрічної, морфрологічної та ін.) визначено й правописну, якою випускник має оволодіти, оскільки українська мова розглядається не тільки як навчальний предмет, а й як засіб опанування інших предметів навчального плану, а також пріоритетний засіб писемної комунікації, який має важливе суспільне значення для ефективного спілкування та інтелектуального й духовного самовираження, який передбачає активне використання рідної мови в різних комунікативних ситуаціях. Проте реалії сьогодення, результати зовнішнього незалежного оцінювання випускників закладів загальної середньої освіти, анкетування й інтерв'ювання студентів та викладачів свідчать: правописна грамотність, зокрема орорографічна, помітно знижується, що зумовлено причинами загального характеру, соціокультурними та лінгводидактичними.

Тривалий час наукові дослідження шляхів підвищення рівня правописної грамотності як учнів, так і студентів вичерпувалися пошуками універсальних методів навчання орфографрії та пунктуації або вдосконаленням внутрішньої організації уроків вивчення правопису. Проблема фрормування правописної компетентності майбутніх учителів початкової школи як важливого складника їхньої 
фрахової компетентності в науковому полі лінгводидактики вищої школи перебуває на периферії наукового пошуку. До сьогодні немає виокремленого тлумачення поняття «правописна компетентність студентів», яке розглядається в контексті мовної компетентності, не приділяється достатньої уваги графрічній, орфографрічній, пунктуаційній субкомпетенціям, які служать підґрунтям для засвоєння студентами інших розділів мовознавчої науки, не існує концептуально обґрунтованої й практично апробованої методики фрормування правописної компетентності студентів педагогічних фракультетів закладів вищої освіти.

Проблема формування й розвитку правописної компетентності майбутніх учителів початкової школи залишається важливою протягом усього часу навчання у виші, особливо в період проходження студентами педагогічної практики. Тому одним із пріоритетних завдань викладачів-фрілологів закладів вищої освіти є підготовка фрахівців, які добре володіють нормами усного та писемного мовлення, мають високий рівень сорормованості графрічних умінь і навичок, орфографрічної та пунктуаційної грамотності і правописної компетентності в цілому. Особливої актуальності ця проблема набула в період реформування Нової української школи.

Висновки і перспективи досліджень. Висновки і перспективи досліджень. Як бачимо, підготовка вчителя початкової школи в контексті вимог Нової української школи та інтеграції в європейський освітній простір вимагає принципової корекції. Нині оновлення змісту професійно-педагогічної підготовки вчителів в Україні визначається впливом процесів інтеграції, технологізації та формуванням загальноєвропейського освітнього простору, глобальними соціокультурними перетвореннями та новою концепцією розвитку суспільства. Тому модернізація національної системи освіти в Україні потребує нового підходу до педагогічної підготовки майбутніх учителів початкової школи, вимагає визначення концептуальних стра- тегій у напрямі подальшого вдосконалення та розвитку педагогічної освіти, що розглядається нами як перспектива подальших наукових розвідок.

\section{БІБЛІОГРАФІЧНИЙ СПИСОК:}

1. Великий тлумачний словник сучасної української мови (з дод. і доп.) / уклад. і голов. ред. В. Т. Бусел. Київ; Ірпінь : ВТФ «Перун», 2005. 1728 с.

2. Енциклопедія освіти / гол. ред В. Г. Кремень. Київ : Юрінком Інтер, 2008. 1040 с.

3. Болонський процес і навчання впродовж життя :зб. наук. праць / упоряд. : М. Ф. Степко, Б. В. Клименко, Л. Л. Товажнянський. Харків, 2004. $111 \mathrm{c}$.

4. Гузій Н. В. Педагогічний професіоналізм : історико-методологічні та теоретичні аспекти : монограсрія. К. : НПУ ім. М. П. Драгоманова, 2004. 243 с.

5. Про освіту : Закон України. URL: https://zakon. rada.gov.ua/go/2145-19.pdf.

6. Про вищу освіту : Закон України URL: https:// zakon.rada.gov.ua/go/1556-18.pdf..

7. Національна стратегія розвитку освіти в Україні на 2012-2021 роки. URL: http://oneu.edu.ua/ wp-content/uploads/2017/11/nsro_1221.pdf

8. Концепції реалізації державної політики у ссрері ресрормування загальної середньої освіти «Нова українська школа» на період до 2029 року : веб-портал органів виконавчої влади України. URL: https://www.kmu.gov.ua/npas/249613934.

9. Андрущенко В. П. Роздуми про вчителя. Вища освіта України. 2011. № 2. С. 6-8.

10. Шапошнікова І. М. Тенденції перебудови системи підготовки вчителя початкових класів. Підготовка вчителя початкової школи в умовах нової парадигми освіти : матеріали Міжнар. наук.-метод. конф., 1-2 квіт. 2004 р. Київ, 2004. С. 77-80.

11. Кремень В. Г. Підготовка вчителя в умовах переходу загальноосвітньої школи на новий зміст, структуру і 12-річний термін навчання. Вища школа. 2003. № 1. C. 3-11.

12. Гончаренко С. У. Методика як наука. Хмельницький : Вид-во ХГПК, 2000. 30 с.

13. Бех І. Д. Виховання особистості : навч.-метод. посіб. : у 2 кн. Кн. 2 : Особистісно-орієнтований підхід : науково-практичні засади. Київ : Либідь, 2003. 344 c. 